\title{
The Effect of Omeprazole Drug on the Blood Picture of Laboratory Rat Rattus Norvegicus
}

\author{
Suhad Y. Jassim ${ }^{1}$, Amer M. Hussin ${ }^{1}$ \\ I (Iraq Natural History Research Center and Museum / University of Baghdad, Bab Al-Muadham, Iraq)
}

\begin{abstract}
In the current study the long-term effect of omeprazole was determined by measuring some hematological parameters .Three groups of laboratory rats were taken each group (6) individual, the first groups was the control, second and third were given the drug with a dose of 20 and 40 respectively for three consecutive months. There are significant effects at $(p>0.05)$ in all parameters which include white and red blood cells counts(WBC and $R B C$ ), Hemoglobin concentration $(H b)$ and the ratio of neutrophils and lymphocytes in both treated groups(the effect is significant for both doses) compared with control, That is, there was a clear effect of omeprazole on the blood picture.
\end{abstract}

Keywords: Drugs, Omeprazole, Toxicology, Hematological parameters Anemia, Albino rats.

\section{Introduction}

The drug omeprazole is included in a group called (proton pump inhibitors) [1], [8]. It reduces the amount of acid in the stomach. It is also used in the treatment of gastro- esophageal reflux disease (GERD) and other conditions associated with increased acidity, it also treats damage to the esophagus Caused by the high rate secretion of gastric acid [12]. In addition Omeprazole is used to prevent gastric (stomach) ulcers caused by bacterial infections which result from proliferation of Helicobacter pylori [13]. After orally administration, Omeprazole is absorbed from the small intestine and carried by the blood to the parietal cell of the stomach [22]. There are many studies on omeprazole Most of these studies relate to the histological effect on the digestive system [23]; [9] , as for studies of its effect on blood, they are very few, [15] recorded no significant effect of omeprazole on blood, [5] mentioned that 22 hematological effects: leucopenia and agranulocytosis have been reported but Most studies indicate no significant effect of Omeprazole on blood, generally Excessive use of medicines can cause hematologic effects [17] ; [14] In another study, there was a clear effect of omeprazole on blood [2]. The aim of this study is to assess the effect of long-term taking of Omeprazole drug on the blood picture by performing some hematological parameters.

\section{Animals}

\section{Materials and Methods}

Male Wister rats (Albino) age 6 weeks, weighting (40-60g) was obtained from the Animal House located in the Museum of Natural History Research Center (Baghdad). Rats were housed in a temperature of $\left(22 \pm 2 \mathrm{c}^{\circ}\right)$ and light $(12: 12 \mathrm{~h})$ light: dark and feed on commercial standard pellets diet [10]; [9]. Rats were divided in to three equal groups $(\mathrm{n}=6$ ), first group was the control (untreated), second was administered orally $20 \mathrm{mg} / \mathrm{kg}$ and the third group was given $40 \mathrm{mg} / \mathrm{kg}$ once daily [4] The experiment lasted three months during this, rats weights were measured weekly.

\section{Collection and Blood Samples}

The equivalent of $(3 \mathrm{ml})$ of blood was withdrawn from the heart directly With a $5 \mathrm{ml}$ syringe after anesthetizing the animal and stabilizing it on the anatomy plate, And then discharged into anticoagulants tubs [21]. Some hematological tests were measured in the laboratory such as hemoglobin concentration, counts of Red and white blood cell, and the differential count of leukocytes Which includes the proportion of both lymphocytes and neutrophils, the measure of these parameters were carried out based on laboratory standard methods [6].

\section{Statistical analysis}

Data were analyzed statistically using Analysis of Variance (AOVA) test and the significant differences between the experimental groups were calculated within a probability level of $(\mathrm{P}>0.05)$ [19]; [16]

\section{Results and Discussion}

Table (1) shows means, standard deviation and Standard error of (WBC) values where the results indicate a significant difference at ( $\mathrm{p}>0.05$ ) For the two treated groups of 20 and $40 \mathrm{mg} / \mathrm{kg}$ Compared to the control group; meaning that there is a significant increase in the counts of WBC was observed. Similar 
conclusion for (Hansen and Bruserud, 2016) But differs with the reach of [15] and [13] where they confirmed the absence of significant effect of Omeprazole on hematological measurements including the WBC count. As is known an increase in the number of WBC indicates an infection in the body [3]. In my opinion, the significant increase in white blood cells indicates that taking omeprazole for a long time helps in the occurrence of internal infections and this in turn stimulates an increase in the WBC number to protect the body because it is considered a defensive method.

\begin{tabular}{|c|c|c|c|c|c|c|c|c|}
\hline & \multirow[t]{2}{*}{$\mathrm{N}$} & \multirow[t]{2}{*}{ Mean } & \multirow{2}{*}{$\begin{array}{c}\text { Std. } \\
\text { Deviation }\end{array}$} & \multirow[t]{2}{*}{ Std. Error } & \multicolumn{2}{|c|}{ 95\% Confidence Interval for Mean } & \multirow[t]{2}{*}{ Minimum } & \multirow{2}{*}{$\begin{array}{c}\text { Maximu } \\
\mathrm{m}\end{array}$} \\
\hline & & & & & Lower Bound & Upper Bound & & \\
\hline Cont & 6 & 9.2000 & 1.81108 & .73937 & 7.2994 & 11.1006 & 6.50 & 11.00 \\
\hline $20 \mathrm{mg}$ & 6 & 11.9333 & 4.47780 & 1.82805 & 7.2342 & 16.6325 & 5.00 & 17.50 \\
\hline $40 \mathrm{mg}$ & 6 & 16.6000 & 1.56844 & .64031 & 14.9540 & 18.2460 & 14.20 & 18.40 \\
\hline Total & 18 & 12.5778 & 4.17958 & .98514 & 10.4993 & 14.6562 & 5.00 & 18.40 \\
\hline
\end{tabular}

Table (1), Means, Std. Deviation and Std. Error of WBC values

Table (2) displays Analysis of Variance (AOVA) test of WBC values among the three groups on the one hand and variation within groups on other hand, the difference is significant among the three groups.

\begin{tabular}{|c|c|c|c|c|c|}
\hline \multicolumn{7}{|c|}{ ANOVA } \\
\hline & Sum of Squares & Df & Mean Square & F & Sig. \\
\hline Between Groups & 168.018 & 2 & 84.009 & 9.772 & .002 \\
\hline Within Groups & 128.953 & 15 & 8.597 & & \\
\hline Total & 296.971 & 17 & & & \\
\hline
\end{tabular}

Table (2) Analysis of Variance test (WBC)

With regard to Red Blood Cells (RBC) values, they are shown in Table (3) which showed means, standard deviation and Standard error of values. In this study, there is a significant decrease in the number of red blood cells for the first and second group in comparison with control at ( $p>0.05)$. These results also apply to hemoglobin values shown in table (5) this indicates an obvious anemia in the treated groups this supports findings of [18], where there were significant decrease in values of RBC and Hb While [7] pointed out that there are no significant differences, [2] confirmed that there were few effects of omeprazole causing anemia. In general, an increase in the duration of taking any medicine has side effects where they cause disorders in red cells, platelets, and the coagulation system [17], It is also known that the basic function of erythrocytes is to transport hemoglobin and the low concentration of hemoglobin in the blood is evidence of anemia [3] This confirms the apparent effect of Omeprazole in the current work. Table (4) also shows variation test among and within the three groups. As is clear the difference is significant. Table (6) shows (ANOVA) analysis and differences between groups and the differences within the groups of $\mathrm{Hb}$ values.

\begin{tabular}{|l|r|r|r|r|r|r|r|r|}
\hline & $\mathrm{N}$ & Mean & Std. Deviation & \multirow{2}{*}{ Std. Error } & \multicolumn{2}{|c|}{ 95\% Confidence Interval for Mean } & \multirow{2}{*}{ Minimum } & \multirow{2}{*}{ Maximum } \\
\cline { 6 - 7 } & & & & & Lower Bound & \multicolumn{2}{|c|}{ Upper Bound } & \\
\hline Cont & 6 & 8.1333 & .61860 & .25254 & 7.4842 & 8.7825 & 7.40 & 9.00 \\
\hline $20 \mathrm{mg}$ & 6 & 5.3833 & .80104 & .32702 & 4.5427 & 6.2240 & 4.50 & 6.50 \\
\hline $40 \mathrm{mg}$ & 6 & 4.6167 & .96626 & .39448 & 3.6026 & 5.6307 & 3.50 & 6.00 \\
\hline Total & 18 & 6.0444 & 1.72907 & .40755 & 5.1846 & 6.9043 & 3.50 & \\
\hline
\end{tabular}

Table (3) Means, Std. Deviation and Std. Error of RBC values

\begin{tabular}{|c|c|c|c|c|c|}
\hline \multicolumn{6}{|c|}{ ANOVA } \\
\hline & Sum of Squares & Df & Mean Square & $\mathrm{F}$ & Sig. \\
\hline Between Groups & 41.034 & 2 & 20.517 & 31.436 & .000 \\
\hline Within Groups & 9.790 & 15 & .653 & & \\
\hline Total & 50.824 & 17 & & & \\
\hline
\end{tabular}

Table (4) Analysis of Variance Test (RBC)

\begin{tabular}{|c|c|c|c|c|c|c|c|c|}
\hline & \multirow[t]{2}{*}{$\mathrm{N}$} & \multirow[t]{2}{*}{ Mean } & \multirow[t]{2}{*}{ Std. Deviation } & \multirow[t]{2}{*}{ Std. Error } & \multicolumn{2}{|c|}{ 95\% Confidence Interval for Mean } & \multirow[t]{2}{*}{ Minimum } & \multirow[t]{2}{*}{ Maximum } \\
\hline & & & & & Lower Bound & Upper Bound & & \\
\hline Cont & 6 & 14.5000 & 1.04881 & .42817 & 13.3993 & 15.6007 & 13.00 & 16.00 \\
\hline $20 \mathrm{mg}$ & 6 & 9.3333 & 1.03280 & .42164 & 8.2495 & 10.4172 & 8.00 & 11.00 \\
\hline $40 \mathrm{mg}$ & 6 & 6.6667 & 1.36626 & .55777 & 5.2329 & 8.1005 & 5.00 & 8.00 \\
\hline Total & 18 & 10.1667 & 3.51886 & .82940 & 8.4168 & 11.9166 & 5.00 & 16.00 \\
\hline
\end{tabular}

Table (5) Means, Std. Deviation and Std. Error of Hb values 
The Effect Of Omeprazole Drug On The Blood Picture Of Laboratory Rat Rattus Norvegicus

\begin{tabular}{|l|r|r|r|r|r|}
\hline \multicolumn{7}{|c|}{ ANOVA } \\
\hline & Sum of Squares & Df & Mean Square & F & Sig. \\
\hline Between Groups & 190.333 & 2 & 95.167 & 70.785 & .000 \\
\hline Within Groups & 20.167 & 15 & 1.344 & & \\
\hline Total & 210.500 & 17 & & & \\
\hline
\end{tabular}

Table (6) ANOVA analysis of $\mathrm{Hb}$

The results of the percentages of Neutrophil are shown in the tables (7) which explains a significant increase in the percentage of neutrophils $i$.e there are significant differences in the values of neutrophils at (0.05) level among the three groups (Table 8, 9).

\begin{tabular}{|c|c|c|c|c|c|c|c|c|}
\hline & $\mathrm{N}$ & Mean & Std. Deviation & Std. Error & $95 \%$ Confidenc & val for Mean & Minimu & Maximum \\
\hline & & & & & Lower Bound & Upper Bound & & \\
\hline Cont & 6 & 15.6667 & 2.33809 & .95452 & 13.2130 & 18.1203 & 13.00 & 19.00 \\
\hline $20 \mathrm{mg}$ & 6 & 23.0000 & 5.45381 & 2.22651 & 17.2766 & 28.7234 & 17.10 & 33.00 \\
\hline $40 \mathrm{mg}$ & 6 & 31.1983 & 5.82775 & 2.37917 & 25.0825 & 37.3142 & 25.30 & 40.30 \\
\hline Total & 18 & 23.2883 & 7.93471 & 1.87023 & 19.3425 & 27.2342 & 13.00 & 40.30 \\
\hline
\end{tabular}

Table (7) Means, Std. Deviation and Std. Error of Neut. values

\begin{tabular}{|l|r|r|r|r|c|}
\hline & Sum of Squares & Df & Mean Square & F & Sig. \\
\hline Between Groups & 724.446 & 2 & 362.223 & 15.709 & .000 \\
\hline Within Groups & 345.867 & 15 & 23.058 & & \\
\hline Total & 1070.313 & 17 & & & \\
\hline
\end{tabular}

Table (8), ANOVA test of neut.

\begin{tabular}{|c|c|c|c|c|c|c|}
\hline \multirow[t]{2}{*}{ (I) Treat } & \multirow[t]{2}{*}{ (J) Treat } & \multirow{2}{*}{$\begin{array}{l}\text { Mean Difference } \\
(\mathrm{I}-\mathrm{J})\end{array}$} & \multirow[t]{2}{*}{ Std. Error } & \multirow[t]{2}{*}{ Sig. } & \multicolumn{2}{|c|}{ 95\% Confidence Interval } \\
\hline & & & & & Lower Bound & Upper Bound \\
\hline \multirow[t]{2}{*}{ Cont } & $20 \mathrm{mg}$ & $-7.33333^{*}$ & 2.77235 & .018 & $-13.2425-$ & $-1.4242-$ \\
\hline & $40 \mathrm{mg}$ & $-15.53167-^{*}$ & 2.77235 & .000 & $-21.4408-$ & $-9.6225-$ \\
\hline \multirow[t]{2}{*}{$\operatorname{mg}$} & Cont & $7.33333^{*}$ & 2.77235 & .018 & 1.4242 & 13.2425 \\
\hline & $40 \mathrm{mg}$ & $-8.19833^{*}$ & 2.77235 & .010 & $-14.1075-$ & $-2.2892-$ \\
\hline \multirow[t]{2}{*}{$40 \mathrm{mg}$} & Cont & $15.53167^{*}$ & 2.77235 & .000 & 9.6225 & 21.4408 \\
\hline & $20 \mathrm{mg}$ & $8.19833^{*}$ & 2.77235 & .010 & 2.2892 & 14.1075 \\
\hline \multicolumn{7}{|c|}{ Table (9) Dependent Variable of Neut. } \\
\hline
\end{tabular}

Table (10) shows results of Lymphocytes percentages represented by Mean, Std. Deviation and Std. Error. There were also significant increases in lymphocyte values among the three groups (table 11). Differences are significant at the 0.05 level between the control group and the $(20,40 \mathrm{mg} / \mathrm{kg})$ groups but not significant between the 20 and 40 group (table 12). These results are consistent with what has been achieved ([7] while [15] Note that there are no significant differences in Neut. and Lymph. Values. As mentioned above, the high increase in leukocytes in the body is caused by the occurrence of infection and they form a defensive line against any damage to the body [20]; [3]. This increase may also be caused by excessive taking of Omeprazole for a long time caused a case of poisoning led to stimulate the leukocytes to protect the body.

\begin{tabular}{|c|c|c|r|r|r|r|c|c|}
\hline & N & Mean & Std. Deviation & Std. Error & \multicolumn{2}{|c|}{$95 \%$ Confidence Interval for Mean } & Minimum & Maximu \\
\cline { 5 - 7 } & & & & & Lower Bound & Upper Bound & & \\
\hline Cont & 6 & 62.4167 & 8.55510 & 3.49260 & 53.4386 & 71.3947 & 50.30 & 70.50 \\
\hline $20 \mathrm{mg}$ & 6 & 77.9583 & 5.84486 & 2.38616 & 71.8245 & 84.0921 & 70.50 & 85.50 \\
\hline $40 \mathrm{mg}$ & 6 & 77.5267 & 10.53827 & 4.30223 & 66.4674 & 88.5859 & 60.50 & 89.33 \\
\hline Total & 1 & 72.6339 & 10.93327 & 2.57700 & 67.1969 & 78.0709 & 50.30 & 89.33 \\
& 8 & & & & & & \\
\hline
\end{tabular}

Table (10) Table (10) shows ANOVA analysis of Lymph.

\begin{tabular}{|c|c|c|c|c|c|}
\hline \multicolumn{6}{|c|}{ ANOVA } \\
\hline & Sum of Squares & Df & Mean Square & $\mathrm{F}$ & Sig. \\
\hline Between Groups & 940.084 & 2 & 470.042 & 6.456 & .009 \\
\hline Within Groups & 1092.036 & 15 & 72.802 & & \\
\hline Total & 2032.120 & 17 & & & \\
\hline
\end{tabular}

Table (11) ANOVA test of Lymph. 
The Effect Of Omeprazole Drug On The Blood Picture Of Laboratory Rat Rattus Norvegicus

\begin{tabular}{|c|c|c|c|c|c|c|}
\hline \multicolumn{7}{|l|}{ LSD } \\
\hline \multirow[t]{2}{*}{ (I) Treat } & \multirow[t]{2}{*}{ (J) Treat } & \multirow{2}{*}{$\begin{array}{c}\text { Mean Difference } \\
(\mathrm{I}-\mathrm{J})\end{array}$} & \multirow[t]{2}{*}{ Std. Error } & \multirow[t]{2}{*}{ Sig. } & \multicolumn{2}{|c|}{$95 \%$ Confidence Interval } \\
\hline & & & & & Lower Bound & Upper Bound \\
\hline \multirow[t]{2}{*}{ Cont } & $20 \mathrm{mg}$ & $-15.54167-^{*}$ & 4.92620 & .007 & $-26.0416-$ & $-5.0417-$ \\
\hline & $40 \mathrm{mg}$ & $-15.11000-^{*}$ & 4.92620 & .008 & $-25.6100-$ & $-4.6100-$ \\
\hline \multirow[t]{2}{*}{$20 \mathrm{mg}$} & Cont & $15.54167^{*}$ & 4.92620 & .007 & 5.0417 & 26.0416 \\
\hline & $40 \mathrm{mg}$ & .43167 & 4.92620 & .931 & $-10.0683-$ & 10.9316 \\
\hline \multirow[t]{2}{*}{$40 \mathrm{mg}$} & Cont & $15.11000^{*}$ & 4.92620 & .008 & 4.6100 & 25.6100 \\
\hline & $20 \mathrm{mg}$ & $-.43167-$ & 4.92620 & .931 & $-10.9316-$ & 10.0683 \\
\hline
\end{tabular}

\section{Conclusion}

From this work can be concluded that taking omeprazole for three months (long-term) With a dose of 20 and $40 \mathrm{mg} / \mathrm{kg}$ influence significantly on hematological parameters, In other words: significant differences were recorded in values of WBC, $\mathrm{RBC}, \mathrm{Hb}$, Lymphocytes and Neutrophil Of the groups of rats that were given omeprazole with a dose of 20 and $40 \mathrm{mg} / \mathrm{kg}$ (treated groups) compared with control (untreated) group. In future studies, the effect of omeprazole can be verified on some biochemical parameters such as its effect on the liver and kidney functions and other organs.

\section{Acknowledgements}

The authors would like to express their appreciation For support provided by the Animal House located in Iraq Natural History Research Center and Museum/ University of Baghdad, especially the Lecturer / Mahmoud Hussein Abdul Rahman for his great help and in completing this study. Very grateful to Professor Dr. Ezeddin Albayyar- Faculty of Science/ University of Al-Anbar for helping to complete statistical analysis.

\section{References}

[1] Andersson T, Cederberg C, Edvardsson G, Heggelund A and Lundborg P, Effect of omeprazole treatment on diazepam plasma levels in slow versus normal rapid metabolizers of omeprazole, Clin Pharmacol Ther, Jan; 47(1), 1990, 79-85.

[2] Avigan M, M.D and C.M, Executive Summary of Safety Profile for Omeprazole-Mg( MEDICAL OFFICER'S REVIEW), January (p1-28), 2000.

[3] Bamishaiye E,Muhammad N,Bamishaiye O, Hematological parameters of albino rats fed on Tiger nuts (Cyperus esculentus) Tuber oil Meal-Based Diet, The internet journal of nutrition and Wellness; vol.10, no.1, 2009.

[4] Bennett R W ,Persaud TVN, Moore K L: Teratological, studies with aluminum in the rat, Teratology; vol.9, 1974, 8-14.

[5] Castot A1, Bidault I, Dahan R, Efthymiou ML, Evaluation of unexpected and toxic effects of omeprazole (Mopral) reported to the regional centers of pharmacovigilance during the first 22 postmarketing months, Clin Pharmacol Ther, Sep-Oct;48(5), 1993, 46974.

[6] Dacie JV\&Lewis S M, Practical hematology (CHURCHILL LIVINGSTONE an imprint of Elsevier Limited, 11th ed, 2011).

[7] Hansen Are -Bent and Bruserud Øyvind, Hypomagnesemia as a potentially life-threatening adverse effect of omeprazole, Oxford Medical Case Reports, Jan; 7, 2016, 147-149.

[8] Hasanin A H, Impact of omeprazole on bone remodeling in normal and ovariectomized Wistar rats, Eur Rev Med Pharmacol Sci, Jul;18(13), 2014, 48-56

[9] Hirose H, Koji T and Susumu O, Effect of Indomethacin on Gastric Mucosal Blood Flow Around Acetic Acid-Induced Gastric Ulcers in Rats American Gastroenterological Association, Published by Elsevier Inc, vo. 100, no. 5, May, 1991, $1259-1265$.

[10] Jassim S Y, The Effect of the type of food on the Efficiency of the liver enzymes GPT and GOT in Black rat Rattus rattus (Linnaeus, 1758), Int.J.Curr.Microbiol.App.Sci: 5(5), 2016, 822-825.

[11] Koolhaas, Koolhaas, J. M, The laboratory rat. In R. Hubrecht, \& J. Kirkwood (Eds.), the UFAW Handbook on the Care and Management of Laboratory and Other Research Animals (Eighth Edition, 2010) 311-326.

[12] Larsson H,Matsson H,Sandell G and Carlsson E, Animal pharmacodynamics of omeprazole. A survey of its pharmacological properties in vivo, Scand J Gastroenterol Suppl: published online: 108, 08 Jul, 1985, 23-35.

[13] Lind T,Cederberg C, Ekenved G,Haglund U \& Olbe L, Effect of omeprazole - a gastric proton pump inhibitor on Penta gastrin stimulated acid secretion in man, Gut: 24, 1983, 270-276.

[14] Lubran M M, Hematologic Side Effects of Drugs, ANNALS OF CLINICAL AND LABORATORY SCIENCE, Vol. 19, 1989, No. 2 .

[15] Maton P N,Vinayek R,Frucht H,McArthur K A,Miller A S,Saeed Z A,Gardner J D and Jensen R T, Long-term efficacy and safety of omeprazole in patients with Zollinger-Ellison syndrome: A prospective study, ELSEVIER Gastroenterology V( 97), NO. 4, October, 1989, 827-836.

[16] Mcdonald J H, Hand book of Biological statistics (Sparky House Publishing Baltimore, Maryland, 2008).

[17] Mintzer M David, Billet N. Shira, and Chmielewski Lauren, Drug-Induced Hematologic Syndromes, Hindawi Publishing Corporation Advances in Hematology: 2009, Article ID 495863, 11 pages.

[18] Scholl S; Dellon S E and Shaheen N J, Treatment of GERD and Proton Pump Inhibitor Use in the Elderly: Practical Approaches and Frequently Asked Questions, Am J Gastroenterol: 106, 2011, 386-392.

[19] Steel RGO, Torrie JH, Principles and Procedures of Statistics (London: Mc Graw Hill Book Company Inc. 1960).

[20] Swash M, Mason S, Hutchison's clinical methods (18th ed.East Sussex Bailliere Tindall; 1984:34).

[21] Tahmasebpour N, Dehghan G, Feizi H M \& Esmaeili A H, Variation in body weight and some hematological parameters in streptozotoch-induced diabetic rats, treated with Teucrium orientale Pharmacology Online: vol.3 ,30 Dec, 2013, 32-36.

[22] Vaz-da-Silva M,; Loureiro I A; Nunes T; Maia J; Tavares S; Falcão A; Silveira P; Almeida L; Soares -da-Silva P, Bioavailability and Bioequivalence of Two Enteric-Coated Formulations of Omeprazole in Fasting and Fed Conditions, Clin Drug Invest.;25(6), 2005, 391-399.

[23] Wei G, Hai-Y L, Li-X W, Li-J H , Jian-L G, Rong-J Z, Chun-J C , and Yan-L S, Protective effect of omeprazole on gastric mucosal of cirrhotic portal hypertension rats, Asian Journal of Tropical Medicine: Volume 7, Issue 5, May, $2014,402-406$. 